\title{
COMPARATIVE PERFORMANCE OF THE VISEGRAD GROUP BANKS FOR THE PERIOD 2009-2013
}

\author{
Liběna Černohorská, Anatoliy Pilyavskyy, William Aaronson
}

\section{Introduction}

Banks are financial institutions that mediate payments, provide loans and take deposits from clients. The banking system has become an important component in the economic sector of each country. Like other industries, the banking industry has its own unique characteristics and specifics that adapt to internal and external influences economic sector. Each country requires a reliable and stable banking system to assure the proper functioning of the economy. The problems in the banking sector will likely have an impact on the entire financial sector. The banking system of each country has its own specifics that influence global globalization. It operates on banking systems around the world. Each state receives it but in different ways. Some states retain more of their traditional banking features that arose during the development of the system, in turn, take some elements of the globalized economy.

In 2007-2008 a financial crisis struck the global economy. A number of large banks in the USA and the European Union required bailing out by government intervention. In the better cases, profit declined by tens of percentage points or showed actual losses. This was not, however, the case for Czech, Slovak and Polish banks. Banks from these countries survived the financial crisis without the need or necessity of government intervention and, in most cases, even achieved distinct profit. One of the reasons for these excellent - and, in Europe, unique results is considered to be the fact that only a few years had gone by since a costly bailout of the banks by the government, during which the banks had not been able to accumulate poor quality assets. At that time, the government was required to spend hundreds of millions of dollars to save the largest banks. Subsequently, foreign financial groups privatized these banks. As of this point, foreign entities have acquired nearly all Czech, Slovak and Poland banks. The banking sectors in these three countries are characterized by unprecedented stability and have shown very healthy profits, despite the global financial and economic crisis of 2007 and 2008 (Teplý et al., 2010). The competitive ability of transition economies within the global financial markets became apparent.

Financial sector companies which are under the supervision of the Czech National Bank showed a significant level of stability during the last economic recession. In addition to the banks themselves, other companies from the sector such as insurance companies also maintained their performance. Subsidiaries of many international financial groups even helped mitigate the negative impact exerted on the parent companies abroad. Bank business activities are mainly financed from domestic deposits, which is well illustrated with relatively stable loan-to-deposit ratio around $75 \%$. The key profitable financial activities remain interest income and fees, which makes Czech banks less vulnerable to financial-market turmoil. Despite the previous protracted recession, the share of non-performing loans shows gradual declining trend since end-2010. Return on assets (RoA) of almost $90 \%$ of the Czech banks exceeds $1 \%$ (which is supposed to be relatively sound level in banking sector). Both main profitability indicators (RoA and RoE) of the Czech banking sector significantly outperform not only the Eurozone's average but WesternEuropean regional peers as well. (Czech National Bank, 2012)

Poland's banking sector is the biggest banking market in the central and eastern European region. The country's banking sector is $70 \%$ owned by foreign investors. During the global financial crisis, Polish banks were affected by the mortgages issued in Swiss francs. Polish banks could recover relatively 
quickly, thanks to the $3.8 \%$ economic growth last year and the re-pricing of risk. Some of the foreign parent banks have sold their Polish units this year to tide over the crisis in their home markets. Still other foreign banks deem this an opportunity to enter the lucrative Polish market. Despite being relatively small in the European scenario the Slovak banking system is a significant sector of the economy. Since 2000 , following restructuring and privatisation of large banks and significant entry of foreign capital, the system has gradually begun to consolidate and to achieve stability. Banks operating in Slovakia reached an important turning point during 2010. After a deep drop in profits in 2009 the banking sector recovered throughout last year. Year 2009 was the worst year for corporate entities, including banks, in recent periods. Under the influence of negative impacts of the economic decline on companies and people, profits of the banking sector more than halved in 2009. The second factor that positively affected the 2010 results was a reduction in the number of failed or failing loans which was reflected in banks lowering their reserves for bad or non-performing loans.

Privatization of Hungarian banks and foreign ownership in banking sector made a major contribution to the successful transformation of the command economy. This process also helped Hungary in applying for membership in the European Union (EU) and becoming a member state in 2004. Consequently, Hungary had to standardize and align its regulations to make them fully EU-conform. Among the main causes of the poor financial situation of Hungary we can include first and foremost the economic crisis, but also inefficient for the policy banks and governments in the pre-crisis years, which has led to failed states and the private sector abroad. The foreign currency loans, without careful examination of foreign exchange risk caused the deepening financial crisis, which led to the economic downturn in the country. Increase payments on the one hand contributed to the tightening of credit conditions, on the other hand, banks have extended by loan maturity to ensure their return. Hungary was between states hard hit by the credit crunch despite the fact that did not play a role in the development of the crisis, as banks from dealing with toxic American securities (or a minimum amount). Hungarian cause of the credit crunch, the economic vulnerability which resulted from the economic policy promoting consumption in the period 2001-2006. The profitability of the Hungarian banking sector showed a downward trend already before the crisis, and due to the economic downturn it did not change in 2008 . The decrease in profitability during the years 2008-2009 mirrored RoE and RoA. Of the Visegrad Group (VG) banks, only the Hungarian bank sector remains unprofitable after 2010 mainly due to the implementation of a bank tax (Dec \& Maiukiewicz, 2011). However, the government of Hungary tried to resolve the situation through use of public funds. In 2013 a tax on financial transactions was imposed. All of this could have led to decreasing support from local branches from foreign parent banks in Hungary (The Economist, 2013).

The aim of this article is to examine the comparative performance of Banks for the Visegrad group (V4) of four Central European States for the period 2009-2013.

The paper is organized as follows. In the first section, we present a review of literature in the area of bank efficiency and bank activity model. In section 2 DEA method, the technique of forming and decomposing of Malmquist index is considered. In section 3 the data and model that we made use of for calculations are presented. In section 4 the main results of the research are discussed. In section 5 we make conclusions.

\section{Theoretical Background}

Economic analyses are used as a foundation for decision making by bank management. At the same time, economic analyses are used extensively by government bodies that regulate and oversee the financial markets. They are also used when adopting adequate measures for preserving the stability of the banking sector (Vodová, 2013; Černohorská \& Černohorský, 2014).

We can find many studies which describe bank efficiency in Visegrad countries and employ Data Envelopment Analysis (DEA). The group of Visegrad countries includes the Czech Republic (Cz), Hungary ( $\mathrm{Hu})$, Poland (Po) and Slovakia (Sk). Due to importance of banking sector efficiency to macroeconomic stability and strong competitive pressure in this sector, a substantial research was done to measure efficiency of banking institutions in developed countries and to benchmark them (Zimková, 2014). As to studies which cover individual 
banking systems in Visegrad countries, Řepková and Stavárek (2013) analysed the Czech banking sector and its efficiency over the period of 2000 to 2009. Repková (2014) applied DEA window analysis on the data of the Czech commercial banks and to examine the efficiency of the Czech banking sector during the period 2003-2012. The paper employed an extended DEA approach, specifically DEA window analysis for the efficiency assessment of commercial banks in the Czech Republic. The group of large Czech banks were lower efficient than other banks in the banking industry. The reasons of the inefficiency of the group of large banks were the excess of deposits in balance sheet and inappropriate size of operation. Wozniewska (2008) examined the efficiency of the Polish banking sector over the period of 2000 to 2007.

The first attempt to estimate commercial banks' efficiency in the Visegrad region before joining the EU and also to consider differences in efficiency across the countries is mentioned in Stavárek (2003). Palečková (2015) examined the efficiency of the banking sectors in Visegrad countries during the period 2009-2013. The results show that average efficiency was slightly decreasing within the period 2010-2011. But significant decrease in efficiency in 2012, it was probably as a result of financial crisis. Then average efficiency increased in 2013. This finding confirms results of Anayiotos et al. (2010) who presented that banking efficiency decreased during the crisis period.

Stochastic Frontier Analysis (SFA) is the most frequently used parametric method. The disadvantage of this method is that this model have to be exactly defined. Many authors use nonparametric approach for bank efficiency ranking (e.g. Holod \& Lewis, 2011; Apergis \& Alevizopoulou, 2011; Kamecka, 2010). The DEA is a nonparametric method use in operations research and economics for the estimation of production frontiers. Nonparametric methods that include DEA and Free Disposal Hull (FDH) do not put any restrictions on the functional form of the relationship between inputs and outputs. This feature of nonparametric methods is particularly appealing for estimating efficiency of financial institutions, which do not have a well defined production function. Parametric methods, such as the Stochastic Frontier Approach (SFA), the Distribution-Free Approach (DFA), and the Thick Frontier Approach (TFA), assume a specific functional form for the cost, profit, or production function. This restrictive nature of the parametric methods is their main disadvantage compared to the nonparametric methods. On the other hand, parametric methods allow for a random error in the estimation process, while nonparametric methods do not. There is no agreement in the literature as to which of the methods is preferable. (Holod \& Lewis, 2011)

Stavárek and Řepková (2013) mentioned that the advantage of the DEA model is that the technique works without the need for standardization. Classical DEA models rely on assumption that inputs have to be minimized and outputs maximized (Charnes, Cooper, \& Rhodes, 1978). Casu and Molyneux (2000) compare parametric and non-parametric estimates of productivity change in European banking between 1994 and 2000. They find that the competing methodologies do not yield markedly different results in terms of identifying the main components of productivity growth. This results correspondent with Mukherjee et al. (2001) findings for US banking. Stavárek and Řepková (2013) founded that the average efficiency in the Czech commercial banks in the period 2001-2010 remained nearly unchanged during the period of estimation. All these authors used the simply constant returns to scale and variable returns to scale.

Pilyavskyy and Matsiv (2009; 2010) employed non-parametric DEA method (Charnes et al., 1978; Banker et al., 1984) to study banking efficiency in Ukraine. Based on these methods, we measure efficiency of the Visegrad group banks using data envelopment analysis (DEA). Secondly, we use DEA for measurement and decomposition of the Malmquist index for analysis of productivity changes in the Visegrad group banks (Malmquist, 1953; Fare et al., 1994a; Fare et al., 1992). We assess efficiency and productivity changes of the Visegrad group banks from the beginning of 2009 till the end of 2013 .

One of the greatest problems in efficiency assessment of bank using DEA method is choosing of inputs and outputs. The question has not been fully solved by this time. This is associated with a specification of bank activity, since bank resources can also be services at the same time and the products are not homogeneous. However, several methodological approaches to estimation of 
inputs and outputs of bank branches were formed in the literature; still choosing of a specific of them fully depends upon the aims of a research and availability of the necessary data.

The two methods that are most frequently used are production and intermediation approaches. Using production approach banks are considered to be "producers" of services for debtors and investors. For the first time this approach was suggested in (Benston, 1965). A set of inputs in this approach consists only of physical variables (or the costs associated with it), such as labour, production area, materials, information systems. The aggregate inputs do not contain interest costs. Outputs are represented by the services the clients are offered. These services are determined through the type and quantity of transactions. In case of lack of such detailed data, quantitative data on time deposits, current deposits and loan accounts are used.

In intermediation approach banks are considered financial intermediaries between debtors and investors. Banks "produce" intermediary services drawing deposits and other liabilities and placing them into profitmaking assets (loans, securities etc.). This approach was used in one of early researches of bank efficiency (Colwell \& Davis, 1992). The inputs in this approach can be represented by either non-interest or interest costs, while inputs - by loans, securities and other profit-making assets. Within the bounds of intermediation approach the discussion of the nature of deposits goes on, i.e. whether to consider them to be inputs or outputs. The discussion resulted in appearance and development of asset approach, user cost approach and valueadded approach, which can be considered the versions of intermediation approach.

Asset approach (Sealey \& Lindley, 1977) is a model form of bank activity, where bank plays a role of a classic intermediary between a debtor and investor. Deposits together with real resources (labour and physical capital) make inputs of the model. A set of outputs consists only of bank assets, such as loans and securities. Asset approach is more often applied on the level of bank systems rather than for assessment of bank branches efficiency.

User costs approach (Hancock, 1985) determines the relation of a financial product either to inputs or outputs, depending on its net contribution to the bank profit. If the product profit exceeds the alternative fund costs or liability costs are lower than asset income, such a product is considered to be an output variable, otherwise - an input variable.

In value-added approach (Berger et al., 1987) those balance sheet accounts are considered to be outputs, which bring in the bank the highest added value. According to this approach deposits and loans are definitely treated as outputs.

In operation approach (Tripe, 2005) the ultimate aim of banking is to get an income. The inputs of this approach are percent and nonpercent costs and the outputs, respectively percent and non-percent incomes.

Modern approach or risk-management approach (Jemric \& Vujcic, 2002; Mester, 1996) integrates risk-management into the classic theory of firm. This approach brings assets quality and probability of bankruptcy into efficiency assessment.

\section{Methodology of Research}

We use the output distance function offered by Shepherd (Shepherd, 1970) for the analysis of efficiency and productivity changes in the Visegrad group banks. The function allows the measurement of technical efficiency of a bank with respect to the production frontier and allows answering the following question: to what extent can output quantities be proportionally expanded without changing the input quantities. We evaluate the output distance functions on the basis of a non-parametric method of frontier analysis - Data Envelopment Analysis (DEA). We use these functions for efficiency measurement and for creating Malmquist index that is used for productivity comparison.

Let us consider $N$ banks, each of them uses $\mathrm{n}$ inputs for producing $\mathrm{m}$ outputs. Then, let $x_{i} \in \mathfrak{R}_{+}^{n}$ and $y_{i} \in \mathfrak{R}_{+}^{m}$ denote input and output vectors for the i-th bank. We consider each bank in two periods of time $t=0$ and $t=1$. Then a production technology transforming inputs into outputs can be presented in the form of the following set:

$$
S^{t}=\left\{\left(x^{t}, y^{t}\right) \mid x^{t} \text { can produce } y^{t}\right\}(1)
$$

A set of outputs is defined as:

$$
P^{t}\left(x^{t}\right)=\left\{y^{t} \mid\left(x^{t}, y^{t}\right) \in S^{t}\right\}
$$


Note that the set $S^{t}$ can represent a certain production technology only when it meets some properties (for more details see Fare and Primont, 2012).

Shepherd's output distance function (Shepherd, 1970) for bank $i$ is defined on the output set as:

$$
D_{i}^{t}\left(x_{i}^{t}, y_{i}^{t}\right)=\inf \left\{\theta \mid \theta>0, y_{i}^{t} / \theta \in P^{t}\left(x^{t}\right)\right\}
$$

In practice the function (3) for bank i can be calculated with the help of DEA, solving the following linear programming (LP) problem:

$$
\begin{aligned}
& {\left[D_{i}^{t}\left(x_{i}^{t}, y_{i}^{t}\right)\right]^{-1}=\max \left\{\varphi_{i} \mid-\varphi_{i} y_{i}^{t}+\right.} \\
& \left.+Y^{t} \lambda \geq 0, x_{i}^{t}-X^{t} \lambda \geq 0,1 \lambda=1, \lambda \geq 0\right\}
\end{aligned}
$$

LP problem (4) makes it possible to receive a value of parameter that measures bank's efficiency, if a technology is characterized by variable return to scale (VRS). But in case it is characterized by constant return to scale (CRS), the problem (4) must be solved without the constraint: $1 \lambda=1$.

The production technology under assumption of CRS ( ) can be defined from set:

$$
\hat{S}^{t}=\left\{\left(\lambda x^{t}, \lambda y^{t}\right) \mid\left(x^{t}, y^{t}\right) \in S^{t}, \lambda>0\right\}
$$

The technology (5) is also called a cone technology. For set $\hat{S}^{t}$, analogically as for set $S^{t}$ the following notions are introduced: a set of outputs $\hat{P}^{t}$ and output distance functions $\hat{D}^{t}$.

Technical efficiency (TE) of a bank measured under assumption of CRS can be presented as a product of pure technical efficiency (PTE) (the result of solution of the LP problem (4)) and scale efficiency. Scale efficiency (SE) is calculated as follows:

$$
S E^{t}=\frac{\hat{D}^{t}\left(x^{t}, y^{t}\right)}{D^{t}\left(x^{t}, y^{t}\right)}
$$

If there are data about activity of a bank for two periods of time $t=0$ and $t=1$, outputs distance function for bank $i$ in the period $t=0$ can be defined with respect to the technology of the period $\mathrm{t}=1$ :

$$
\begin{aligned}
& D_{i}^{1}\left(x_{i}^{0}, y_{i}^{0}\right)=\inf \left\{\theta \mid \theta>0, y_{i}^{0} /\right. \\
& \left./ \theta \in P^{1}\left(x^{1}\right)\right\}
\end{aligned}
$$

Distance function $D_{i}^{0}\left(x_{i}^{1}, y_{i}^{1}\right)$ is built analogically.
Building of such functions allows us to use Malmquist's idea (Malmquist, 1953) for analysis of banking productivity. In the papers (Fare et al., 1994a; Fare et al., 1992) the following Malmquist-type index (Total Factor of Productivity (TFP)) was suggested to be used:

$T F P^{0,1}=\left(\frac{D^{0}\left(x^{1}, y^{1}\right)}{D^{0}\left(x^{0}, y^{0}\right)} \cdot \frac{D^{1}\left(x^{1}, y^{1}\right)}{D^{1}\left(x^{0}, y^{0}\right)}\right)^{1 / 2}$

A value of the index (8) greater than 1 indicates increasing of productivity, a value less than 1 indicates decreasing.

Decomposition of the index (8) is rather a significant point of productivity changes analysis for discovering the potential sources of increasing total factor of productivity. In the papers (Fare et al., 1994a; Fare et al., 1992), decomposition of TFP onto two components - efficiency change and technological change was performed. Technical efficiency change $(E C)$ is measured in the following way:

$$
E C^{0,1}=\frac{D^{1}\left(x^{1}, y^{1}\right)}{D^{0}\left(x^{0}, y^{0}\right)}
$$
follows:

Technological change (TC) is measured as

$$
T C^{0,1}=\left(\frac{D^{0}\left(x^{1}, y^{1}\right)}{D^{1}\left(x^{1}, y^{1}\right)} \cdot \frac{D^{0}\left(x^{0}, y^{0}\right)}{D^{1}\left(x^{0}, y^{0}\right)}\right)^{1 / 2}
$$

As in the case with the index (7), the fact that values (8) and (9) are greater (less) than 1 indicates positive (negative) changes of efficiency and technology respectively. So

$$
T F P^{0,1}=E C^{0,1} \cdot T C^{0,1}
$$

\section{Data}

In this paper we used annual data on the activity of Czech, Slovak, Poland and Hungarian commercial banks (without foreign bank branches, credit unions, mortgage banks, building societies and state banks with special purposes) during 2009-2013 that were published in the database Bankscope (data net loans, total securities, fixed assets, deposits and short term funding) and in annual reports of selected banks (data number of employees). 
Our data set contained 205 observations. We chose ten banks from the Czech Republic, eight banks from Hungary, eleven from Poland and twelve from Slovak.

Several banks (four banks from the Czech Republic, fifteen banks from Hungary, seventeen from Poland and five banks from Slovak) were removed from the data set as far as they have other conditions for work than the commercial ones. Banks that had in a set period of time at least one input or output equal to zero were also excluded out of the data set. So the final data set for measuring of efficiency of selected banks contained 205 observations. The share in total banking sector assets selected banks is on average over $80 \%$ in the Czech Republic and Hungary and over $70 \%$ in Poland and Slovak, in given period. (Bankscope, 2015) Selected banks can be considered as a representative sample of selected banking sectors and the data set includes significant parts of all banking sector.

Specification of inputs and outputs is one of the major problems for measurement of bank's efficiency and productivity changes. To determine inputs and outputs, we made use of assets approach (Sealey \& Lindley, 1977) that treats banks as classical intermediates between depositors and borrowers. Řepková (2014) employed for DEA window analysis two inputs (labor and deposits), and two outputs (loans and net interest income). This author measures labor by the total personnel costs covering wages and all associated expenses and deposits by the sum of demand and time deposits from customers, interbank deposits and sources obtained by bonds issued. Loans are measured by the net value of loans to customers and other financial institutions and net interest income as the difference between interest incomes and interest expenses. Wozniewska (2008) defined as outputs the volume of loans, deposits and non-interest income, and the net fixed assets and the total number of employees are defined as input. Stavárek (2003) determined for the DEA model the appropriate number of inputs and outputs with a respect on the dataset size and consequently employed three inputs (labor, capital, and deposits), and two outputs (loans and net interest income). The same output and outputs employed (Řepková \& Stavárek, 2013). Palečková (2015) assumes that the banks' main aim is to transform liabilities (deposits) into loans (assets). There are employed three inputs (labor, fixed assets and deposits), and two outputs (loans and net interest income). There is measure labor by the total personnel costs covering wages and all associated expenses and deposits by the sum of demand and time deposits from customers, interbank deposits and sources obtained by bonds issued. Loans are measured by the net value of loans to customers and other financial institutions and net interest income as the difference between interest incomes and interest expenses. Anayiotos et al. (2010) chose the variables as inputs: total capital, interest expense and operating expense and total loans, pre-tax profit and securities portfolio were chosen as outputs.

We have determined three inputs (personnel, physical capital, purchased funds)

\section{Tab. 1: Descriptive statistics of inputs and outputs}

\begin{tabular}{l|r|r|r|r|r} 
& $\begin{array}{c}\text { Net Loans } \\
\text { th USD } \\
\mathbf{2 0 1 3}\end{array}$ & $\begin{array}{c}\text { Total } \\
\text { Securities } \\
\text { th USD 2013 }\end{array}$ & $\begin{array}{c}\text { Fixed Assets } \\
\text { th USD } \\
\mathbf{2 0 1 3}\end{array}$ & $\begin{array}{c}\text { Deposits \& } \\
\text { Short term } \\
\text { funding } \\
\text { th USD } \\
\mathbf{2 0 1 3}\end{array}$ & $\begin{array}{c}\text { Number of } \\
\text { Employees } \\
\mathbf{2 0 1 3}\end{array}$ \\
\hline Mean & $7,535,614$ & $3,308,057$ & $149,959.7$ & $10,095,488$ & $4,057.532$ \\
\hline Median & $4,617,496$ & $1,255,396$ & 57,590 & $5,367,297$ & 2,302 \\
\hline Standard Deviation & $8,903,289$ & $4,682,699$ & 214,246 & $11,793,878$ & $5,732.452$ \\
\hline Minimum & 36,875 & 3,579 & 42 & 89,761 & 14 \\
\hline Maximum & $46,417,473$ & $23,172,151$ & 992,808 & $48,691,992$ & 32,811 \\
\hline
\end{tabular}


and two outputs: net loans, total securities. All the data are in mil. USD (without number of employees). Physical capital can be measured by the book value of fixed assets. Purchased funds consist of loanable funds that include all the kinds of bank deposits and short term funding and securities emitted by bank. Net loans of a bank contain all the kinds of loans (either for legal entities or individuals) reduced on the sum of reserves. Total securities consist of public and private funds in other banks. Descriptive statistics of inputs and outputs is given in Tab. 1.

\section{Results of the Research \\ 4.1 Analysis of the Efficiency}

The essential goal of the research is measurement of efficiency and productivity changes in the bank sector of Visegrad group banks (VG banks) on the whole. That is why we focus onto the average indices and discovering of tendencies that make it easier to understand the way the bank system of Visegrad group functions from the point of view of efficiency and productivity changes. Thus an individual assessment of a separate bank is not considered in our research.
Mean values of efficiency for the constant return to scale model (crs model), variable return to scale model (vrs model), and scale efficiency of the VG banks are given below in the Fig. 1. As can be seen in Fig. 1 average technical efficiency (for all banks) for the vrs model trended upward during the study period from 0.830 to 0.917 At the same time mean values of efficiency in the crs model trended upward from 0.529 to 0.609 (with decreasing to 0.571 in 2012) and the scale efficiency is almost stable about 0.650 . Let us notice that this increase efficiency is not common for all banks in the Czech Republic, Poland, Hungary and Slovak. In Tab. 2 we can find that efficiency in the crs and the vrs models for Czech, Polish and Slovak banks (see Tab. 2) increase during research time. Development of efficiency Hungarian banks (see Tab. 2) has on the contrary in vrs model a downward trend from 0.882 in 2009 to 0.856 in 2013. In the vrs model in 2013 Czech banks have the highest value of efficiency from monitored banks (0.971) and the Hungarian banks the lowest (0.856). Let us notice also the highest average value of the scale efficiency in 2013 (0.756) for Hungarian banks.

\section{Fig. 1: Efficiency scores for all banks during the study period}

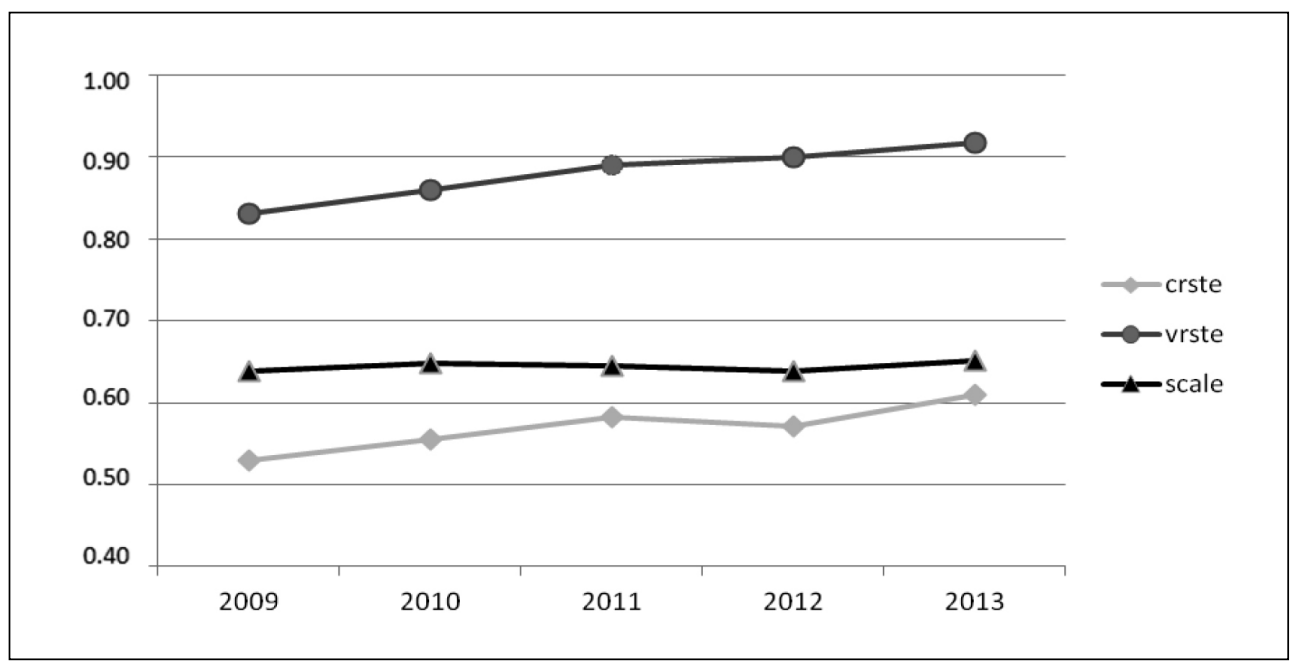

Source: own elaboration

Note: crste - technical efficiency score for the constant return to scale model; vrste - technical efficiency score for the variable return to scale model; scale - scale efficiency 


\begin{tabular}{|c|c|c|c|c|c|c|c|}
\hline $\mathrm{Cz}$ & crste & vrste & scale & Po & crste & vrste & scale \\
\hline 2009 & 0.621 & 0.946 & 0.656 & 2009 & 0.519 & 0.863 & 0.614 \\
\hline 2010 & 0.595 & 0.921 & 0.645 & 2010 & 0.533 & 0.876 & 0.617 \\
\hline 2011 & 0.602 & 0.934 & 0.644 & 2011 & 0.574 & 0.928 & 0.616 \\
\hline 2012 & 0.633 & 0.943 & 0.669 & 2012 & 0.577 & 0.954 & 0.603 \\
\hline 2013 & 0.671 & 0.971 & 0.688 & 2013 & 0.573 & 0.963 & 0.593 \\
\hline $\mathrm{Hu}$ & crste & vrste & scale & Sk & crste & vrste & scale \\
\hline 2009 & 0.594 & 0.882 & 0.686 & 2009 & 0.420 & 0.669 & 0.631 \\
\hline 2010 & 0.632 & 0.867 & 0.729 & 2010 & 0.504 & 0.783 & 0.650 \\
\hline 2011 & 0.634 & 0.877 & 0.728 & 2011 & 0.532 & 0.831 & 0.640 \\
\hline 2012 & 0.545 & 0.805 & 0.696 & 2012 & 0.532 & 0.856 & 0.623 \\
\hline 2013 & 0.646 & 0.856 & 0.756 & 2013 & 0.568 & 0.872 & 0.648 \\
\hline
\end{tabular}

Source: own elaboration

\subsection{Analysis of the Total Factor of Productivity}

We also looked at the Total Factor of Productivity Change (see Tab. 3). The TFP across all countries was relatively stable in 3 of the 4 observation periods. However, there was a substantial decline in TFP in 2011-2012 to 0.954$)$. Examination of the trends for each of the countries showed that Hungary overly influenced the sample mean (see Tab. 4). The TFP remained stable during (about 1.000) this period for all Poland and Czech Republic, declined slightly for Slovakia, but declined precipitously for Hungary in 2011-2012 to 0.751 . Let us notice also that the index of TFP change for Hungarian banks from 2012 to 2013 was the highest (1.212).
In order to understand this trend we examined the underlying variables to see if there was a root cause of the decline. Input variable trended similarly across the four countries. At the same time the output variable "net loans" increased for Polish, Slovak and Czech banks throughout the 4 years (see Tab. 5). However, the value for Hungarian banks declined each year (from 5,151,004.38 th. USD in 23009 to $3,313,570.50$ th. USD in 2013). The value of "total securities" grew for Slovak and Czech banks, but declined for Hungarian banks between 2010 and 2012 (from 1,835,760.00 th. UDS in 2010 to $1,479,625.63$ in 2011) (see Tab. 6).

We then asked why the TFP change would be anomalous for Hungary. Hungary

\section{Tab. 3: Total Factor of Productivity (TFP) change for all banks during the study period}

\begin{tabular}{c|c} 
Year & TFP change \\
\hline $2009 / 2010$ & 1.074 \\
\hline $2010 / 2011$ & 1.049 \\
\hline $2011 / 2012$ & 0.954 \\
\hline $2012 / 2013$ & 1.059 \\
\hline mean & 1.033 \\
\hline
\end{tabular}


Tab. 4:

Comparative Total Factor of Productivity Change for banks during the study period

\begin{tabular}{c|c|c|c|c} 
& $\mathbf{C z}$ & Hu & Po & Sk \\
\hline $\mathbf{2 0 0 9 / 2 0 1 0}$ & 0.994 & 1.095 & 1.016 & 1.191 \\
\hline $\mathbf{2 0 1 0 / 2 0 1 1}$ & 1.012 & 1.038 & 1.081 & 1.058 \\
\hline $\mathbf{2 0 1 1 / 2 0 1 2}$ & 1.036 & 0.751 & 0.986 & 1.016 \\
\hline $\mathbf{2 0 1 2 / 2 0 1 3}$ & 1.049 & 1.212 & 1.012 & 1.017 \\
\hline
\end{tabular}

Source: own elaboration

\section{Tab. 5: Net loans for countries during the study period}

\begin{tabular}{c|r|r|r|r}
\multicolumn{7}{c}{ Net Loans (th USD ) } \\
\hline & \multicolumn{1}{c}{$\mathbf{C z}$} & Hu & Po & \multicolumn{1}{c}{ Sk } \\
\hline $\mathbf{2 0 0 9}$ & $8,927,011.40$ & $5,151,004.38$ & $11,245,522.82$ & $2,953,844.17$ \\
\hline $\mathbf{2 0 1 0}$ & $9,448,379.10$ & $4,704,462.38$ & $12,440,336.82$ & $3,157,286.50$ \\
\hline $\mathbf{2 0 1 1}$ & $9,377,627.20$ & $4,264,459.88$ & $12,950,572.64$ & $3,221,320.42$ \\
\hline $\mathbf{2 0 1 2}$ & $9,572,748.10$ & $3,597,873.88$ & $12,802,936.45$ & $3,429,124.83$ \\
\hline $\mathbf{2 0 1 3}$ & $10,326,889.30$ & $3,313,570.50$ & $14,480,369.91$ & $3,647,279.42$ \\
\hline
\end{tabular}

Source: own elaboration

Tab. 6: Total Securities for countries during the study period

\begin{tabular}{c|c|r|r|r}
\hline \multicolumn{7}{c}{ Total Securities (th USD) } \\
\hline $\mathbf{2 0 0 9}$ & $\mathbf{C z}$ & Hu & Po & Sk \\
\hline $\mathbf{2 0 1 0}$ & $4,539,182.80$ & $1,673,907.75$ & $4,146,345.18$ & $1,206,250.17$ \\
\hline $\mathbf{2 0 1 1}$ & $5,619,595.00$ & $1,995,547.13$ & $4,374,193.55$ & $1,455,116.25$ \\
\hline $\mathbf{2 0 1 2}$ & $5,853,310.10$ & $1,835,760.00$ & $4,646,055.55$ & $1,455,812.92$ \\
\hline $\mathbf{2 0 1 3}$ & $5,742,468.20$ & $1,479,625.63$ & $4,334,709.55$ & $1,417,588.58$ \\
\hline & $6,150,271.40$ & $1,901,441.13$ & $4,537,195.36$ & $1,597,707.25$ \\
\hline
\end{tabular}

Source: own elaboration

had been a trailblazer among the Visegrad group resulting from decades of experience with economic reform beginning in the 1960s (Valentinyi, 2012). However, due to growing indebtedness Hungary's economic position was on the decline when the European banking crisis of 2008 hit. In 2010 a center-right party (Fidesz) was elected in Hungary (Than, 2012). The new government instituted important economic reforms that precipitated a financial crisis in 2011-2012 (Valentinyi, 2012; Simon, 2012). The general economic decline coupled with the financial crisis in 2011-2012 can be seen clearly in the declining value of the output variables compared to the other three countries studied. This largely explains the anomalous results we observed in terms of the TFP change in 2012-2013. 


\section{Conclusions}

In the recent past, a financial crisis struck the global economy. Banks from the Czech Republic, Slovak and Poland survived the financial crisis without the need or necessity of government intervention and, in most cases, even achieved distinct profit. One of the reasons for these excellent - and, in Europe, unique results is considered to be the fact that only a few years had gone by since a costly bailout of the banks by the government, during which the banks had not been able to accumulate poor quality assets. At that time, the government was required to spend hundreds of billions of crowns to save the largest banks; subsequently, these banks were privatized by foreign financial groups. As of this point, nearly all Czech, Slovak and Poland banks have been owned by foreign entities. During the global financial crisis, Polish banks were affected by the mortgages issued in Swiss francs. Polish banks could recover relatively quickly, thanks to the $3.8 \%$ economic growth. Despite early progress toward economic reform, the Hungarian banking sector did not experience the same successful adjustment partly due to decisions made by the Hungarian government and the imposition of a banking tax. We will extend the time series in our further research and analyse the impact of the financial crisis on the bank efficiency in the selected countries (V4).

We would like to make a special remark as to the method of Malmquist index decomposition presented here. It is the most widely used method for differentiation of scale efficiency changes in the scale efficiency. It is rather often criticized. And it is not in vain. The thing is that technological change with such decomposition of Malmquist index is calculated under consumption of CRS, while the scale changes and changes of pure technical efficiency are calculated under consumption of VRS. To get over this fault is possible only by using other methods of Malmquist index decomposition. In Balk's approach (Balk, 2001) seems to be rather perspective.

The paper has been created with the financial support of The Czech Science Foundation (project GACR No. 17-02509S, "Emerging financial risks during a global low interest rate environment").

\section{References}

Anayiotos, G., Toroyan, H., \& Vamvakidis, A. (2010). The efficiency of emerging Europe's banking sector before and after the recent economic crisis. Financial Theory and Practice, 34(3), 247-267.

Balk, B. M. (2001). Scale Efficiency and Productivity Change. Journal of Productivity Analysis, 15(3), 159-183. doi:10.1023/A:1011117324278.

Apergis, N., \& Alevizopoulou, E. (2011). Bank efficiency: Evidence from a panel of European banks. Panoeconomicus, 58(3), 329-341. doi:10.2298/PAN1103329A.

Bankscope database (2015). Bureau van Dijk.

Banker, R. D., \& Charnes, A., \& Cooper, W. W. (1984). Some Models for Estimating Technical and Scale Inefficiencies in Data Envelopment Analysis. Management Science, 30(9), 1078-1092. doi:10.1287/mnsc.30.9.1078.

Berger, A. N., Hanweck, G. A., \& Humphrey, D. B. (1987). Competitive Viability in Banking: Scale, Scope, and Product Mix Economies. Journal of Monetary Economy, 20(3), 501-520. doi:10.1016/0304-3932(87)90039-0.

Benston, G. J. (1965). Branch Banking and Economies of Scale. Journal of Finance, 20(2), 312-331. doi:10.1111/j.1540-6261.1965. tb00212.x.

Casu, B., Girardone, C., \& Molyneux, P. (2004). Productivity Change in European Banking: A comparison of parametric and non-parametric approaches. Journal of Banking \& Finance, 28(10), 2521-2540. doi:10.1016/j.jbankfin.2003.10.014.

Charnes, A., \& Cooper, W. W., \& Rhodes, E. (1978). Measuring the efficiency of decision making units. European journal of operational research, 2(6), 429-444. doi:10.1016/0377-2217(78)90138-8.

Colwell, R. J., \& Davis, E. P. (1992). Outputand Productivity in Banking. Scandinavian Journals of Economics. Computers and Operations Research, 30, 279-295. doi:10.2307/3440252.

Czech National Bank. (2012). Financial Stability Report 2010/2011. Prague: Czech National Bank. Retrieved March 11, 2017, from http://www.cnb.cz/miranda2/export/sites/www. cnb.cz/cs/financni_stabilita/zpravy_fs/fs_20102011/fs_2010-2011.pdf.

Černohorský, J., \& Černohorská, L. (2014). The Criticism of Basel II Based on Credit Risk Modelling. In SGEM2014 Conference Proceedings, 2 (pp. 721-728). 
Dec, P., \& Masiukiewicz, P. (2011). Bank Tax in the European Union. Economics and Applied Informatics. 17(2), 91-96.

Färe, R., Grosskopf, S., Lindgren, B., \& Roos, P. (1992). Productivity changes in Swedish pharamacies 1980-1989: A nonparametric Malmquist approach. In International Applications of Productivity and Efficiency Analysis (pp. 81-97). Springer Netherlands.

Färe, R., Grosskopf, S., Lindgren, B., \& Roos, P. (1994a). Productivity developments in Swedish hospitals: a Malmquist output index approach. In Data envelopment analysis: theory, methodology, and applications (pp. 253-272). Springer Netherlands.

Färe, R., Grosskopf, S., Norris, M., \& Zhang, Z. (1994b). Productivity growth, technical progress, and efficiency change in industrialized countries. The American economic review, 84(1) 66-83.

Färe, R., \& Primont, D. (2012). Multi-output production and duality: theory and applications. Springer Science \& Business Media.

Grifell-Tatjé, E., \& Lovell, C. K. (1999). A generalized Malmquist productivity index. Top, 7(1), 81-101. doi:10.1007/BF02564713.

Hancock, D. (1985). Bank Profitability, Interest Rates and Monetary Policy. Journal of Money, Credit and Banking, 17(2), 189-202. doi:10.2307/1992333.

Holod, D., \& Lewis, H. F. (2011). Resolving the deposit dilemma: A new DEA bank efficiency model. Journal of Banking \& Finance, 35(11), 2801-2810. doi:10.1016/j.jbankfin.2011.03.007.

Jemrić, I., \& Vujčić, B. (2002). Efficiency of Banks in Croatia: A DEA Approach [Working Paper No. 7]. Zagreb: Croatian National Bank. doi:10.1057/ces.2002.13.

Kamecka, M. (2010). Bank efficiency in CEE (Doctoral dissertation). WU Vienna University of Economics and Business.

Malmquist, S. (1953). Index numbers and indifference surfaces. Trabajos de Estadistica y de Investigacion Operativa, 4(2), 209-242.

Mester, L. J.(1996).Astudy of BankEfficiency Taking into Account Risk-Preferences. Journal of Banking and Finance, 20(6), 1025-1045. doi:10.1016/0378-4266(95)00047-X.

Mukherjee, K., Ray, S. C., \& Miller, S. M. (2001). Productivity growth in large US commercial banks: The initial postderegulation experience. Journal of Banking \& Finance, 25(5), 913-939. doi:10.1016/S03784266(00)00103-5.
Palečková, I. (2015). Banking Efficiency in Visegrad Countries: A Dynamic Data Envelopment Analysis. Acta Universitatis Agriculturae et Silviculturae Mendelianae Brunensis, 63(6), 2085-2091. doi:10.11118/ actaun201563062085.

Pilyavskyy, A., \& Matsiv, Y. (2009). Performance of Banks in Ukraine (2005-2008). Zeszyty Naukowe "Współczesne Problemy Zarządzania“, 7-20.

Pilyavskyy, A. I., \& Matsiv, Y. I. (2010). An Analysis of the Efficiency and Productivity of Ukrainian Banks. Studia i Prace Uniwersytetu Ekonomicznego w Krakowie, (11), 91-106.

Ray, S. C., \& Desli, E. (1997). Productivity growth, technical progress, and efficiency change in industrialized countries: comment. The American Economic Review, 87(5), 1033-1039.

Repková, I. (2014). Efficiency of the Czech banking sector employing the DEA window analysis approach. Procedia Economics and Finance, 12, 587-596. doi:10.1016/S22125671(14)00383-9.

Sealey, C. W., \& Lindley, J. T. (1977). Inputs, outputs, and a theory of production and cost at depository financial institutions. The Journal of Finance, 32(4), 1251-1266. doi:10.1111/j.1540-6261.1977.tb03324.x.

Shepherd, R. W. (1970). Cost and Production Functions. Princeton: Princeton University Press.

Stavarek, D. (2003). Banking efficiency in Visegrad countries before joining the European Union. doi:10.2139/ssrn.671664.

Simon, Z. (2012). Hungarian Economy Slips Into Second Recession in 4 Years. Retrieved October 9, 2016, from http://www.bloomberg.com/ news/articles/2012-08-14/hungarian-economyslips-into-second-recession-in-4-years.

Stavárek, D., \& Řepková, I. (2013). Efficiency in the Czech banking industry: A non-parametric approach. Acta Universitatis Agriculturae et Silviculturae Mendelianae Brunensis, 60(2), 357-366.

Teplý, P., Stárová, H., \& Černohorský, J. (2010). Value creation of European bank mergers and acquistitions in the 1998-2007 period. Ekonomický časopis, 58(5), 458-470.

The Economist. (2013). Hungary's central bank. Retrieved June 9, 2015, from http:// www.economist.com/news/europe/21573166government-entrenches-its-power-europeanunions-dismay-orbans-soldiers. 


\section{Finance}

Than, K. (2012). Analysis: Crisisweary Hungarians lose faith in government. Retrieved April 21, 2015, from http://www. reuters.com/article/us-hungary-economyidUSBRE85G08120120617.

Valentinyi, A. (2012) The Hungarian crisis. Retrieved September 13, 2015, from http://voxeu. org/article/hungarian-crisis.

Tripe, D. (2005). The Cost of Funds and Bank Efficiency Through Time. Retrieved April 17, 2015, from http://eprints.otago. ac.nz/630/01/CostofFunds2005.pdf.

Vodová, P. (2013). Liquid assets in banking what matters in the visegrad countries. E\&M Ekonomie a Management, 16(3), 113-129.

Wozniewska, G. (2008). Methods of measuring the efficiency of commercial banks: an example of Polish banks. Ekonomika, 84, 81-91. doi:10.15388/Ekon.2009.0.5124.

Zimková, E. (2014). Window analysis of technical efficiency: case of the Slovak banking system. In 17th Applications of Mathematics and Statistics in Economics, International Scientific Conference (pp. 294-300). doi:10.15611/amse.2014.17.32.
Ing. Liběna Černohorská, Ph.D. University of Pardubice

Faculty of Economics Administration Institute of Economics Science Libena.cernohorska@upce.cz

Prof. \& Chair Anatoliy Pilyavskyy, DSc. Lviv University of Trade and Economics Faculty of International Economic Relations and Information Technology

Department of Higher Mathematics and Quantitative Methods apiliavs@mail.Iviv.ua

Assoc. Prof. \& Chair William Aaronson, Ph.D. Temple University Philadelphia, USA College of Public Health Department of Health Services Administration \& Policy waaronso@temple.edu 


\section{Abstract}

\section{COMPARATIVE PERFORMANCE OF THE VISEGRAD GROUP BANKS FOR THE PERIOD 2009-2013}

\section{Liběna Černohorská, Anatoliy Pilyavskyy, William Aaronson}

The article examines the comparative performance of Banks for the Visegrad group (V4) of four Central European States for the period 2009-2013. We study the technical efficiency as well as the total factor of productivity changes differences between countries by employing the Data Envelopment Analysis. The efficiency scores are calculated with an output-oriented model.

Specification of inputs and outputs is one of the major problems for measurement of bank's efficiency and productivity changes. To determine inputs and outputs, we made use of assets approach that treats banks as classical intermediators between depositors and borrowers. We have determined three inputs (personnel, physical capital, purchased funds) and two outputs: net loans, total securities.

Our results showed that average technical efficiency (for all banks) trended upward during the study period. This increase efficiency is not common for all banks in the Czech Republic, Poland, Hungary and Slovak. We found that efficiency for Czech, Polish and Slovak banks increase during research time. Development of efficiency Hungarian banks has on the contrary a downward trend from 0.882 in 2009 to 0.856 in 2013.

We also founded that the Total Factor of Productivity (TFP) changes across all countries was relatively stable in 3 of the 4 observation periods. However, there was a substantial decline in TFP in 2011-2012. Examination of the trends for each of the countries showed that Hungary overly influenced the sample mean. The TFP remained stable during this period for all Poland and Czech Republic, declined slightly for Slovakia, but declined precipitously for Hungary in 2011-2012.

Key Words: Performance of banks, Visegrad Group, technical efficiency, total factor of productivity changes.

JEL Classification: G34, M12.

DOI: 10.15240/tul/001/2017-2-013 